\title{
Data generation of vector maps using a hybrid method of analysis and selection of geodata necessary to optimize the process of spatial planning
}

\author{
Dominika Strumiłło-Rembowska, Michał Bednarczyk, Iwona Cieślak \\ University of Warmia and Mazury in Olsztyn, Faculty of Geodesy and Land Management, Prawocheńskiego St.15, 10-724 Olsztyn, Poland
}

\begin{abstract}
Throughout the years GIS has developed a number of very useful cartographic tools for the computerized storage, management and graphic display of many thematic layers of particular data and information. The aim of the paper was both to present the possibility of generating data of vector maps and to give an example of hybrid method of analysis and selection of geodata extracted from raster image necessary to optimize the process of spatial planning. The study shows how by using vector maps, fast spatial analysis can be proceeded.
\end{abstract}

Keywords: GIS; spatial planning; vector map; raster map; optimization.

\section{Introduction}

Nowadays, geographic information systems are everywhere. All human actions using space have become a domain in which it is justified to use GIS for various reasons, such as economic aspects, improvement of the quality of actions, or even time saving [4], [13]. In the mid-1980s, some very useful tools were developed in the system which were used to store data in an electronic form, to manage such data and to graphically display many thematic layers, containing data on location and attributes [2].

In the "Lexicon of geomatics", J. Gaździcki [6] defines GIS as a "System used to search, acquire, verify, analyse, transfer and make available spatial data; understood broadly, it includes methods, technical means - hardware and software, spatial database, organisation, resources and people interested in its operation."

Moreover, the GIS system is compatible with statistical software and spreadsheets [10].

One of the functions in which the system can be used is to replace inconvenient analogue sets of data with digital sets [8]. According to Fu-Yung, maps are a graphic presentation of geographic and spatial information. Being a data carrier, it stores and makes the analyses of such data available [1].

"A raster map is a model of geographic space, recorded as a two-dimensional table, a so called raster matrix" [11] whereas "a vector map, also known as a vector model, involves picturing the world with points and lines which present the location of objects or their boundaries" [12].

The outcome of the GIS system operation is visualised in the form of maps. The presentation of data mainly allows the many relationships between objects to be shown.

GIS allows for presentation of maps in a traditional (printed) form, close to paper maps made by cartographers, and as data displayed on a screen, using a software interface.

According to Roth [3], the interaction of the whole process depends on three elements. The first one is a human factor (which arises from the user's perspective), the second is visualisation (focusing on the interface), and the third is the technical factor (focusing on the technical side of the issue).

\section{The Hybrid method of analysis and selection of geodata necessary to optimize the process of spatial planning}

This paper presents an original method of analysis and selection of geodata, which consists of heterogeneous methods of optimisation, which are hybrids structured in a series. This enables more precise and, above all, faster problem solving. The

Corresponding author: Dominika Strumiłło-Rembowska. E-mail address: dominika.rembowska@uwm.edu.pl

http://dx.doi.org/10.3846/enviro.2014.134

(C) 2014 The Authors. Published by VGTU Press. This is an open-access article distributed under the terms of the Creative Commons Attribution License, which permits unrestricted use, distribution, and reproduction in any medium, provided the original author and source are credited. 
hybrid method combines methods of spatial assessment and valuation (Bajerowski's method), numerical taxonomy (Ward's method) and axioms of the theory of planning spatial use (totality axiom).

Cartographic stock-taking of features present in an area is conducted using topographic maps and land register maps. Subsequently, these maps are scanned and fitted in as a raster image. Below (Fig. 1) is an example of the division of the area under analysis into primary fields on a topographic map.

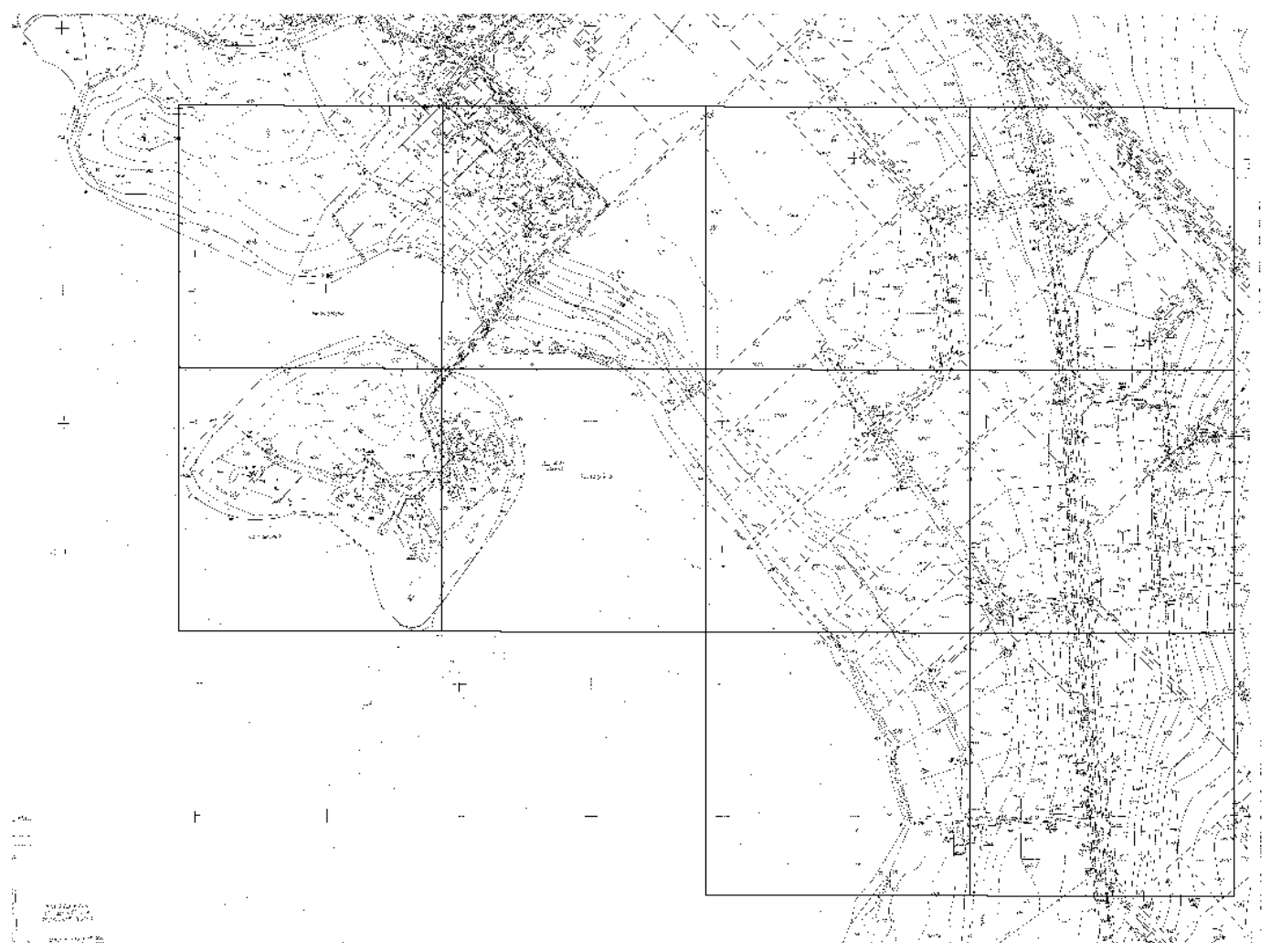

Fig. 1. An example of the division of the area under analysis, situated in Tomaszkowo, into primary fields Source: Prepared by the author based on a topographic map 1:1000. County Office in Olsztyn PODGiK

This method assumes that a study will be conducted in an area covered by a local land use plan. The area was divided into $200 \times 200 \mathrm{~m}$ primary fields, which effectively gives a primary field for assessment with an area of $40,000 \mathrm{~m}^{2}$. Another assumption of the method is that such primary fields are chosen for analysis for which at least $30 \%$ of the area was within the area covered by the local plan.

According to Bajerowski [5], the dimension of a zoning space is equivalent to the number of features of space which allow the position of an object in the space to be determined. In this method, the properties which allow the position of an object in space to be determined are selected features, and the primary field is the analysed object. The probability of the primary field belonging to a certain group of similar fields is determined by the number and type of features which are present in the fields which determine them.

Applying a vector map allows the stage of cartographic (manual) stock taking of features to be eliminated and replaced with a quick analysis of terrain according to the procedure described below.

\section{Applying the hybrid method of analysis and selection of geodata necessary in the process of optimisation of zoning space with vector maps}

Spatial analysis of data was performed with a vector map of the area of Bartag, downloaded in the dxf. format, which was entered in the GeoMedia Professional 6.1 program. The program was selected mainly because it enables using queries for attributes and thematic analysis.

Assigning the attributes involves recording semantic information about objects. It is stored integrally with geometric data of the vector or raster model [11].

Since entering all the thematic layers in the file would make the outcome of the method unclear, only four layers were displayed: the water supply network, embankments, buildings and sewerage system.

The next step involved drawing in the square grid with an area of $200 \times 200 \mathrm{~m}$, within which the analysis was subsequently conducted. The illustration below shows the possibility of obtaining a preview of each field and checking their attributes. Fig. 2 shows the attributes of primary field no. 5. 

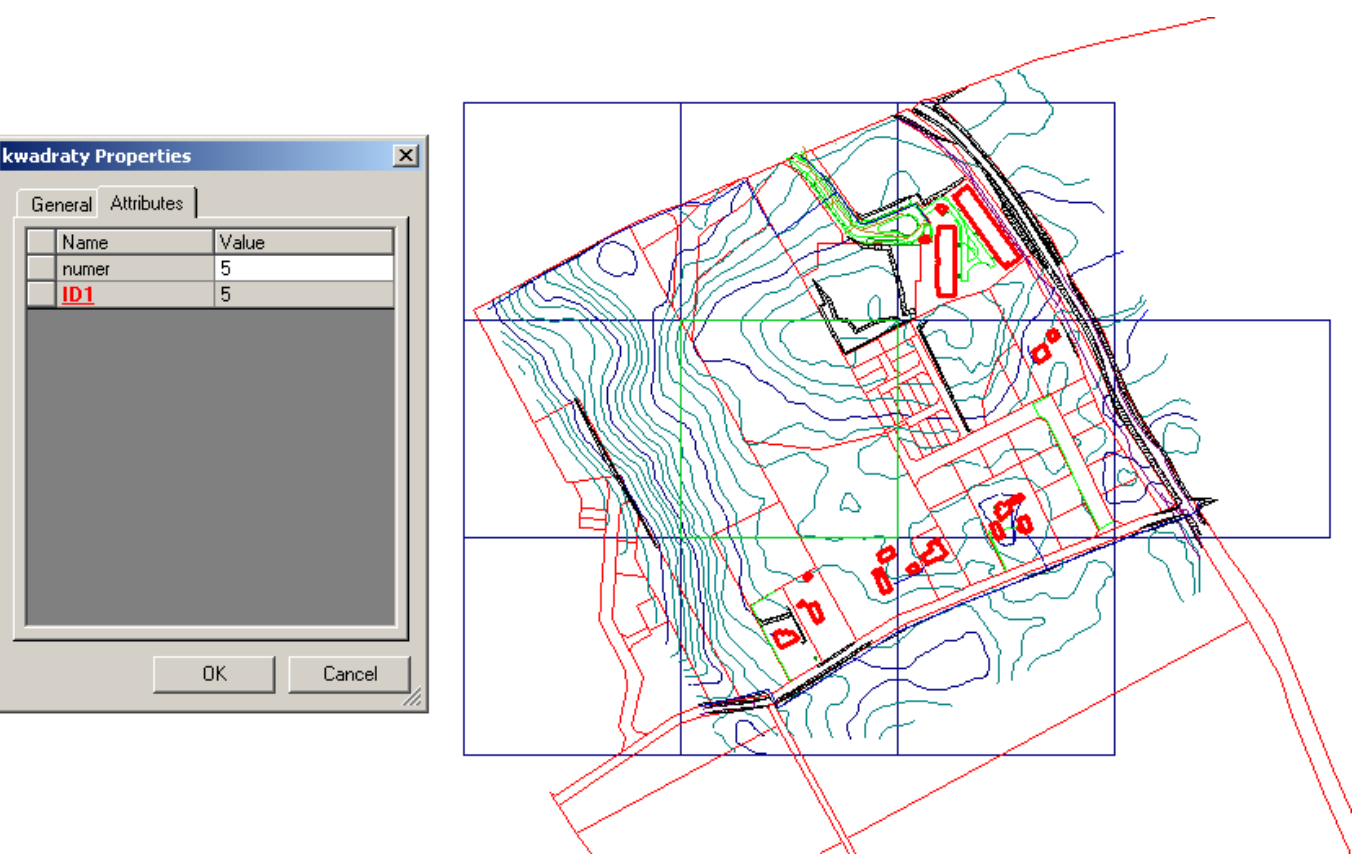

Fig. 2. Attributes of primary fields (square grid)

The analysis can start using the prepared map. The analysis will be conducted by the aggregation of objects sought within the primary field. Aggregation allows objects to be transferred from one class of objects to another in the form of a dynamic query. The criteria of aggregation are selected by the user through tabs in the AGGREGATION dialogue box.

The next step is to add a function attribute in each of the analysed layers. This helps to determine whether an object is within the boundaries of the primary field. It is made possible by applying a query:

\section{IF(COUNT(Detail.Compound.Geometry)>YES;'NO').}

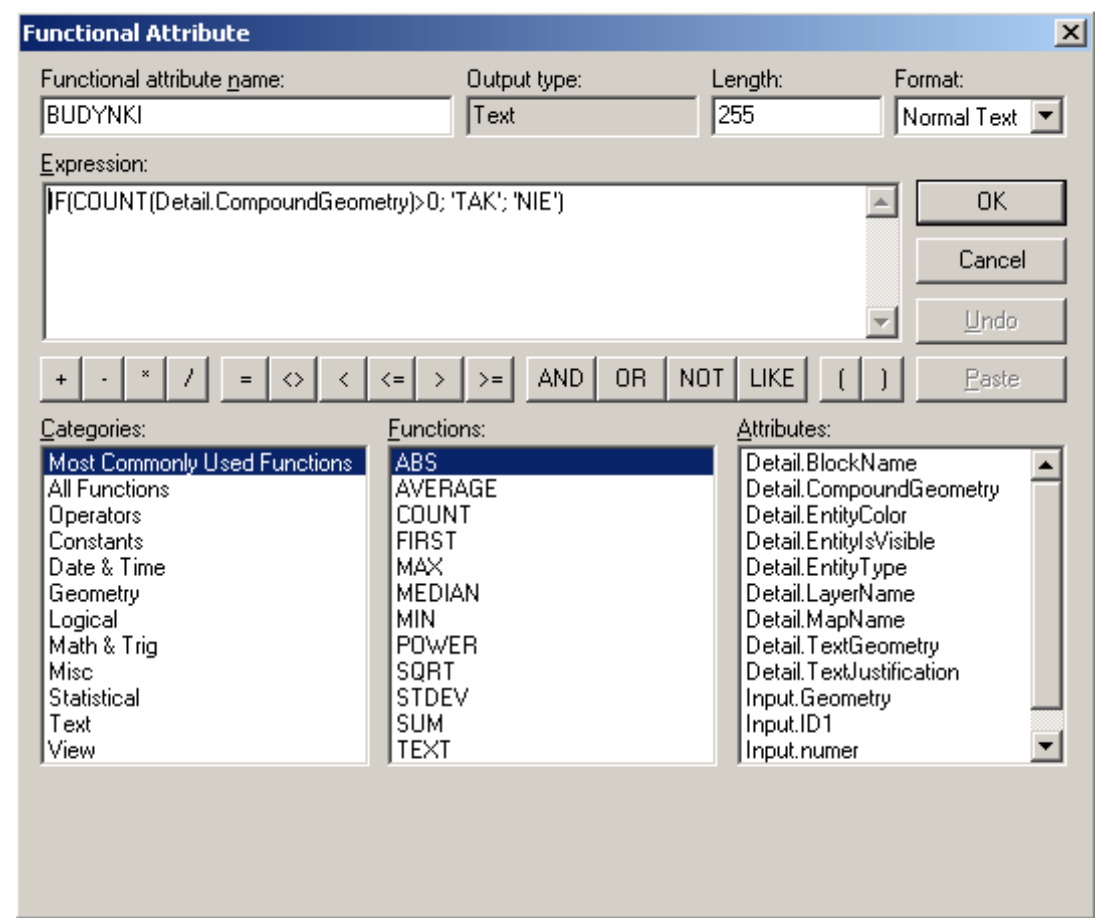

Fig. 3. FUNCTION ATTRIBUTE dialogue box

A graphic presentation of the attributes of an object in the primary field after the aggregation of BUILDINGS is shown below (Fig. 4). 


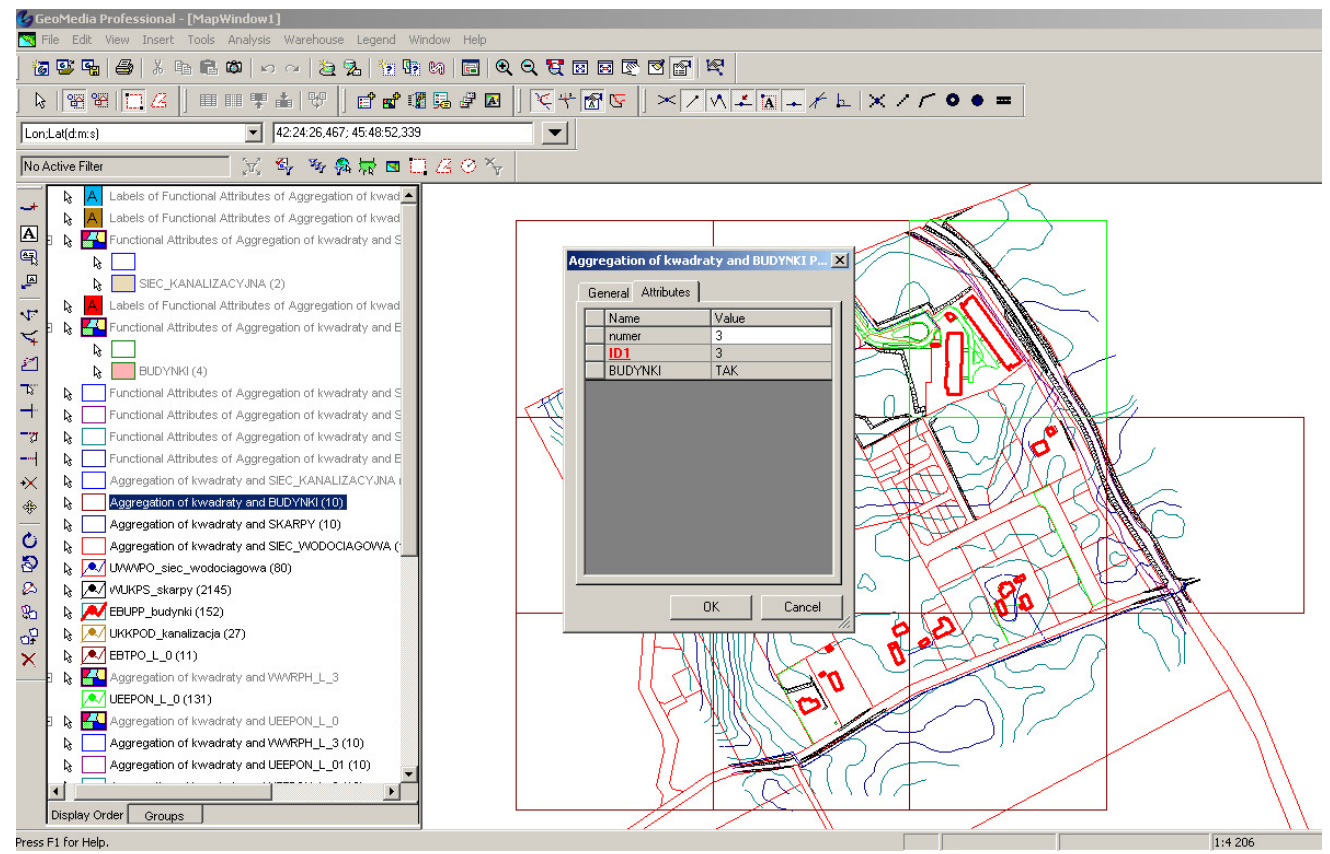

Fig. 4. Presentation of attributes of an object in the primary field after aggregation of BUILDINGS

Labels should be added for the presentation of results. A label can be added in two ways, as a query or as a class of an object. In each case, the attributes of the original objects are copied to the object label, the difference being that attributes in the query label are linked dynamically, so all the changes made in the original properties of an object are reflected on the label object, whereas they are linked statically in the label query, because of which a change of the original object attributes does not affect the object class label.

In the presented method, adding query labels was applied; to this end, the query was used:

$$
\text { IF(Input.BUILDINGS ="YES"," BUILDINGS","”'). }
$$

This allowed us to check if the function attribute (BUILDINGS) lay within the primary field.

Results can be visualised in a variety of ways. Two examples of graphic methods of presentation of attributes in a primary field will be presented. The first method involves assigning an appropriate colour to the primary field in which a specific function attribute is present. The other involved adding labels with names of individual attributes.

Applying specific visual variables is actually linked with the perceptive capabilities of a map user [9]. A colour is selected by a user in accordance with the subjective criteria of his/her aesthetic impressions [7].

Visualisation of attributes by assigning a colour to the primary field is shown in Fig. 5.

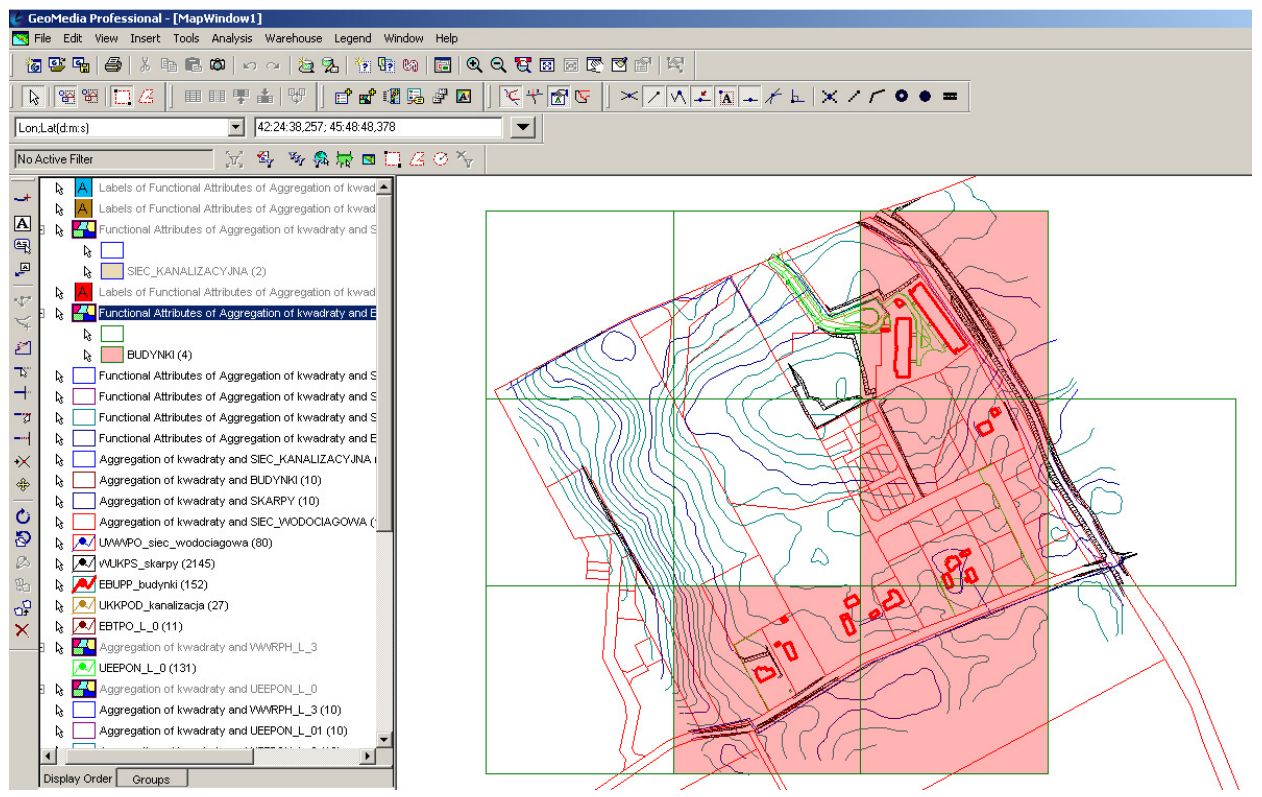

Fig. 5. Graphic presentation of attributes in the primary field following aggregation of BUILDINGS - method one 


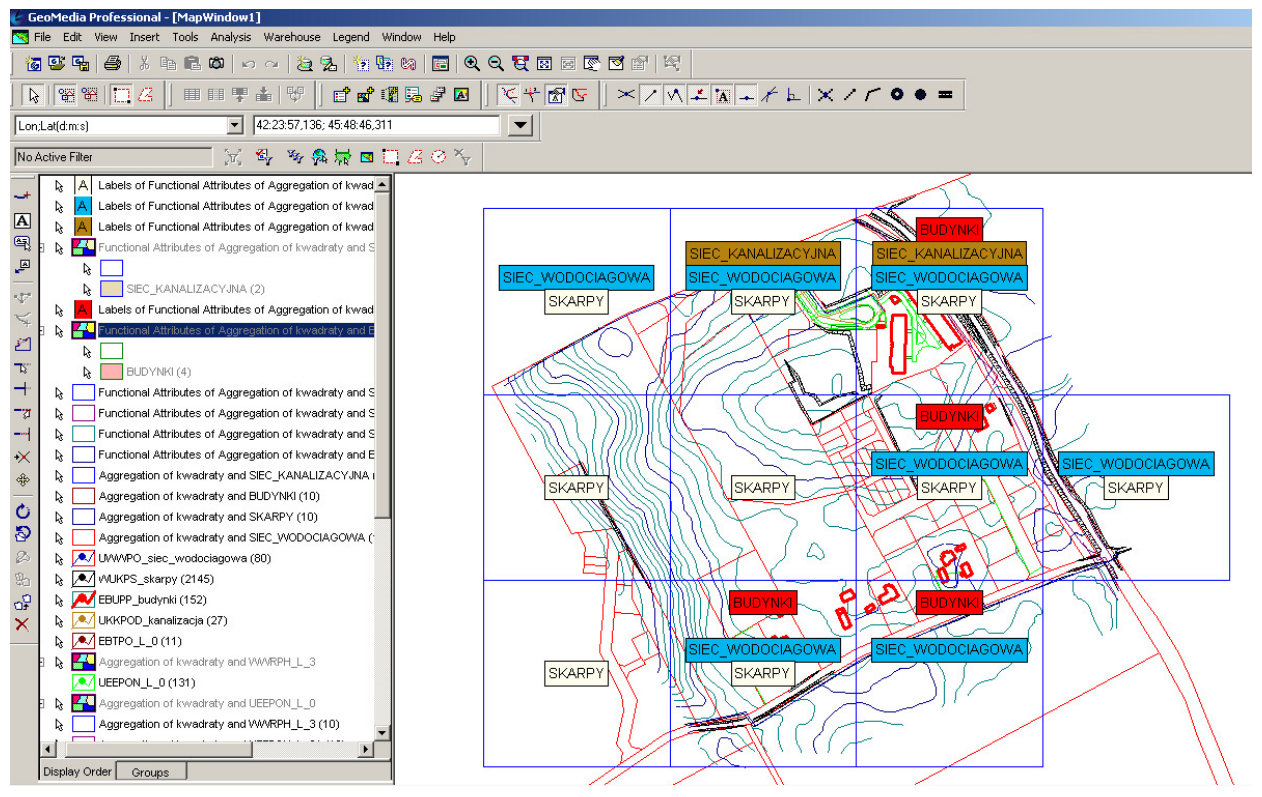

Fig. 6. Graphic presentation of attributes in the primary field - method two

In order to prepare a graphic presentation of the first method, only one thematic layer, "BUILDINGS", was defined. In the second method, labels of all the four layers were added. The main disadvantage of the first method is that after aggregation of several attributes, colours overlap and it is difficult to identify those which are in the analysed area. The method is useful when one specific layer is sought. When several layers are taken for analysis, much better results are obtained by adding labels with the names of attributes on the map, as is shown in Fig. 6.

\section{Conclusions}

The hybrid method of optimisation of zoning space developed by the author is used to identify and find sites of special importance in the process of creating and developing the residential function (and probably others) and to conduct studies and analyses of structures of land use in urban, suburban and rural areas. Applying the method in studies and analyses conducted prior to the proper spatial planning can support and facilitate the decision-making processes. Moreover, this method can prove useful in the vectorisation of spatial data contained in thematic maps. Analogue maps with the geodetic location of spatial objects have been mostly vectorised, whereas the huge resources of spatial data with the geographical dimension of space (such as soil data for agriculture, sociological data, data about natural features) are still available only in the analogous form. The procedure presented here can facilitate the process of data vectorisation, thereby facilitating access to a lot of data which are frequently the basis for comprehensive spatial analyses.

There are various methods of data visualisation. They depend on the user's needs, aims and social groups for which they will be presented. Graphic presentation of information can be helpful in the process of creation and analysing space, which facilitates the operation of the entire system.

Owing to vector maps, we can conduct rapid analyses of a specific area. With access to such a data source, applying a hybrid method of optimisation of zoning space becomes much less labour-intensive. Vector maps help to eliminate the stage of cartographic (manual) stock-taking of features and to replace it with a quick analysis of the system. Additionally, the possibility of analysing the gathered information by making simple queries to databases helps to understand the patterns which may occur in the spatial distribution of phenomena, which, in effect, enables one to make decisions, for example, regarding investments.

Geodata obtained as a result of the analysis can be successfully fed into spatial information systems.

\section{References}

[1] Kuan, F. Y.; Ho, Y. P.; Wang, R.Y.; Chen, C. W. 2013. Using RPC Block Adjustment models for the accuracy of environmental research, cartography and geomarketing: a new concept ofcartography, Stochastic Environmental Research and Risk Assessment 27(6): 1315-1331. http://dx.doi.org/10.1007/s00477-012-0668-8

[2] Richardson, D. B. 2013. Real-Time Space-Time Integration in GIScience and Geography, Annals of the association of american geographers 103(5): 1062-1071. http://dx.doi.org/10.1080/00045608.2013.792172

[3] Roth, R. E. 2013. An empirically-derived taxonomy of interaction primitives for interactive cartography and geovisualization, IEEE transactions on visualization and computer graphics 19(12): 2356-2365. http://dx.doi.org/10.1109/TVCG.2013.130

[4] Walacik, M.; Cellmer, R.; Źróbek, S. 2013. Mass appraisal - international background, Polish solutions and proposal of new methods application, Geodetski list 67(90): 255-269.

[5] Bajerowski, T. 2003. Niepewność $w$ dynamicznych układach wspótrzędnych, Olsztyn, UWM.

[6] Gaździcki, J. 2002. Leksykon geomatyki, Warszawa, Polskie Towarzystwo Informacji Przestrzennej. 
[7] Grosser, K. 2001. Farbe in Kartographie [w:] Lexicon der Kartographie und Geomatik, Bolmann J., Koch W.G. (red.), Heidelberg-Berlin, Spektrum Akademischer Verlag.

[8] Kistowski, M.; Iwańska, M. 1997. Systemy informacji geograficznej. Podstawy techniczne i metodyczne. Przegląd pakietów oprogramowania i zastosowań w badaniach środowiska przyrodniczego, Poznań, Bogucki Wydawnictwo Naukowe, 7-85, 89-93.

[9] Kraak, M.-J.; Ormeling, F. 2003. Cartography: Visualization of Geospatial Data, London, Person Education Limited.

[10] Magnuszewski, A. 1999. GIS w geografii fizycznej, Warszawa, Wydawnictwo Naukowe PWN, 11-20.

[11] Medyńska-Gulij, B. 2011. Kartografia i geowizualizacja, Warszawa, Wydawnictwo Naukowe PWN, $27,91$.

[12] Kowalczyk, K.; Kowalczyk, A. 2008. Selected issues concerning map drawing, in The 7th International Conference "Environmental Engineering 3: 1362.

[13] Szuniewicz, K. 2013. Zastosowanie algorytmów genetycznych w procesie analizy i prognozowania rozwoju terenów miejskich na przykładzie osiedla Jaroty w Olsztynie, $\mathrm{PhD}$ thesis, 28-34. 